\title{
PENINGKATAN PEMAHAMAN FIKIH PADA ANAK DENGAN METODE DEMONSTRASI DI MASA PANDEMI COVID-19 DI TPQ AL- HIKMAH KELURAHAN NGRONGGO KOTA KEDIRI
}

\author{
Muhammad Yahya Khabibi \\ Institut Agama Islam Negeri (IAIN) Kediri \\ mkzfairy@gmail.com \\ Agus Miftakus Surur \\ Institut Agama Islam Negeri (IAIN) Kediri \\ surur.math@gmail.com
}

Agus Subandono

Universitas Pawyatan Daha Kediri

virgokuragil17@gmail.com

\begin{abstract}
Abstrak:
Fikih merupakan materi yang diajarkan sekaligus dipraktikkan dalam kehidupan sehari-hari, terleih bagi santri. Materi fikih mayoritas adalah materi aplikatif, sehingga penerapannya juga menggunakan pembelajaran yang aplikatif, yaitu denagn metode demonstrasi. Metode demonstrasi membuat santri dapat mempraktikkan/memperagakan tentang materi yang sedang dipelajari. Pembelajaran ini dilakukan oleh peneliti, sebagai bentuk pengabdian pada TPQ, sehingga metode yang digunakan adalah PAR (Participatory Action Research). Metode ini menjadikan peneliti terjun langsung ke lapangan dan berupaya untuk meningkatkan pemahaman para santri tentang materi fikih. Hasil dari pembelajaran ini santri mengikuti instruksi dari guru, kemudian mendemonstrasikan tentang materi yang sedang dipelajari. Setelah praktik, pembelajaran dilanjutkan di kelas untk diskusi bersama. Santri diberikan pertanyaan seputar apa saja yang sudah dipraktikkan, para santri berani menjawab dengan menggunakan kalimat sendiri. Dari hasil pembelajaran ini akan selalu ditingkatkan supaya menjadikan pembelajaran menyenangkan dan materi terserap pada diri santri.
\end{abstract}

Kata kunci: fikih; metode demonstrasi; pembelajaran TPQ

\begin{abstract}
:
This community service aims to introduce Figh learning using the demonstration method as an alternative teaching during the Covid-19 pandemic. This community service is based on the Tri Dharma of Higher Education. This community service is a manifestation of the Thematic Real Work Lecture from home (KKN DR) IAIN Kediri program which is carried out virtually and takes into account the applicable health protocols. These activities take various forms, including social media campaigns and teaching. Social media campaigns are used as a form of public education about Covid-19, while teaching is a real form of concern about education during the pandemic. The activity of implementing learning on Figh material using the demonstration method was carried out in Ngronggo Vil lage for TPQ al-Hikmah children with the aim of providing an alternative during religious learning during the pandemic.
\end{abstract}


The results of this service show a positive response, where children can receive Figh learning and demonstrate so that it can help them to learn Islamic religious education more easily and meaningfully.

Keywords: fiqh, demonstration method, TPQ learning

\section{PENDAHULUAN}

Awal tahun 2020 terjadi peristiwa yang mana berpengaruh sampai tingkat internasional, bahkan Indonesia negeri tercinta juga terkena dampak dari peristiwa yang terjadi. Bentuk peristiwa tersebut adalah munculnya penyakit baru yang disebabkan oleh virus Covid-19, sampai merenggut nyawa bagi para korban terjangkit virus tersebut. sehingga satu persatu negara di dunia mengumumkan pembatasan skala besar atau lockdown bertujuan untuk membatasi semua aktivitas yang dilakukan guna mencegah bertambahnya korban dan menekan jumlah angka kematian warga di setiap negara. Adanya kebijakan tersebut mengakibatkan lumpuhnya semua aktivitas warga baik dalam bidang sosial, ekonomi dan tak terkecuali pendidikan. Dalam pendidikan sendiri mengacu pada proses pembelajaran yang biasa dilakukan di sekolah secara langsung. Namun dengan adanya pandemi ini, mau tidak mau harus dihentikan sementara sampai dirasa kondisi sudah membaik. ${ }^{1}$

Dalam bidang pendidikan juga diberlakukan kebijakan baru yaitu semula pembelajaran bersifat luring (luar jaringan) diubah menjadi daring (dalam jaringan). Kebijakan ini dilakukan agar proses pembelajaran tetap berlangsung walaupun tidak bisa berkumpul, akan tetapi dengan memanfaatkan media berupa gadget diharapkan bisa memudahkan proses pembelajaran secara daring terlaksana dan berjalan sesuai yang diharapkan. ${ }^{2}$ Namanya suatu rencana pasti selalu ada halangan sehingga tidak bisa mencapai sesuatu yang diharapkan. Muncul kendala seperti sebagian siswa belum tentu mempunyai gadget, mengeluarkan biaya lebih untuk membeli kuota agar bisa mengakses online, lemahnya jaringan internet di sebagian daerah, serta meningkatnya stres orang tua dalam mendampingi anaknya belajar daring. ${ }^{3}$

Belajar di masa pandemi ini memang tidak bisa disamakan dengan belajar normal. Karena adanya pembatasan alokasi waktu dalam pembelajaran membuat tidak bisa mencapai apa yang diharapkan ${ }^{4}$. Disamping itu kelas dibuat dengan sistem shift atau bergiliran agar mematuhi protokol kesehatan. Dilihat dari situasi tersebut membuat siswa memahami pelajaran tidak bisa maksimal

\footnotetext{
${ }^{1}$ Ni Komang Suni Astini, "Pemanfaatan Teknologi Informasi Dalam Pembelajaran Tingkat Sekolah Dasar Pada Masa Pandemi Covid--19,” LAMPUHY ANG 11, no. 2 (July 1, 2020): 15.

2 Rosyid Ridlo Al Hakim, "Pencegahan Penularan Covid-19 Berbasis Aplikasi Android Sebagai Implementasi Kegiatan KKN Tematik Covid-19 Di Sokanegara Purwokerto Banyumas," Community Engagement and Emergence Journal (CEEJ) 2, no. 1 (2020): 8.

3 Yulita Pujilestari, "Dampak Positif Pembelajaran Online Dalam Sistem Pendidikan Indonesia Pasca Pandemi Covid--19," 'AD ALAH 4, no. 1 (April 19, 2020): 30, https://doi.org/10.15408/adalah.v4i1.15394.

4 Agus Miftakus Surur, Pandi Rais, and Habib, “The Application Program of The Preparation of The Syllabus and Learning Implementation Plan (RPP) 2013 Curriculum on Teachers Madrasah Ibtidaiyah,” Proceedings International Conference on Islamic Education (ICIED) 2, no. 1 (2017): 246-53.
} 
dan mau tidak mau proses pembelajaran berjalan dengan lambat. ${ }^{5}$ Maka dari itu, dalam pembelajaran masa darurat, diberlakukan pemberian pembelajaran dengan pemilihan materi yang sekiranya penting. Tanpa harus berpedoman pada ketuntasan belajar. Karena yang terpenting harus menitikberatkan pada penguatan karakter, praktek ibadah, peduli lingkungan dan kesalehan sosial, serta wajib mempertimbangkan kesehatan dan keselamatan jiwa. Dengan begitu pembelajaran pada kondisi saat ini, bisa berjalan dengan optimal walaupun tidak bisa seperti biasanya. ${ }^{6}$

Kuliah kerja nyata $(\mathrm{KKN})$ adalah bentuk implementasi dari Tri Dharma Perguruan Tinggi sebagai intrakulikuler dalam hal pengabdian masyarakat dengan memakai metode mengenalkan dan mengapreasikan pengalaman kerja serta belajar mahasiswa. ${ }^{7}$ Pelaksanaan KKN di masa saat ini berbeda dengan yang sebelumnya. Pasalnya, dengan adanya pandemi covid-19 yang masih belum mereda mengakibatkan segala aktivitas yang berkaitan dengan praktek lapangan menjadi terbatas dan berbeda seperti kegiatan pengabdian masyarakat yaitu kuliah kerja nyata (KKN). Namun karena kondisinya yang semakin membaik dalam melakukan aktivitas, maka kegiatan KKN bisa tetap dilakukan walaupun harus mematuhi beberapa peraturan. KKN pada tahun 2021 ini dapat dilakukan melalui beberapa macam cara seperti, KKN Mandiri Dari Rumah (KKN-DR) dan KKN Mandiri Berkelompok di Lokasi Desa (KKN-DL). KKN-DR dilakukan secara mandiri di wilayah domisili masing-masing Mahasiswa, namun masih berbentuk kelompok yang dibentuk secara mandiri oleh peserta. Sedangkan KKN-LD dilakukan secara berkelompok di lokasi desa atas ijin instansi desa masing-masing. Proses pembentukan kelompok juga dilakukan secara mandiri oleh Mahasiswa. ${ }^{8}$ Dengan kondisi KKN-DR, maka mahasiswa melakukan kegiatan di lingkungan masingmasing dengan tetap memperhatikan protocol Kesehatan, salah satunya adalah dengan membantu pembelajaran di TPQ.

Taman pendidian al-Qur'an (TPQ) merupakan tempat dimana anak-anak belajar tentang cara membaca al-Qur'an sesuai dengan tuntunan dan mengarjakan berbagai bidang pendidikan agama Islam seperti Fikih, Akidah akhlak, sejarah Islam maupun bahasa Arab. Tujuan dari lembaga ini adalah berupaya mencetak pribadi anak yang Islami yang sesuai dengan tuntunan agama. Serta mempunyai kesadaran untuk selalu melaksanakan ibadah sebagai wujud kewajiban tanpa harus diperintah. Maka dengan begitu, lembaga non formal tersebut sudah menjadi tempat pendidikan tambahan agar lebih berfokus pada aspek keagamaan yang bersifat ibadah sehari-hari.

\footnotetext{
${ }^{5}$ Erna Pujiasih, "Membangun Generasi Emas Dengan Variasi Pembelajaran Online Di Masa Pandemi Covid-19," Ideguru : Jurnal Karya Ilmiah Guru 5, no. 1 (2020): 44.

6 Astini, "Pemanfaatan Teknologi Informasi Dalam Pembelajaran Tingkat Sekolah Dasar Pada Masa Pandemi Covid--19," 16.

7 Syardiansah, "Peranan Kuliah Kerja Nyata Sebagai Bagian Dari Pengembangan Kompetensi Mahasiswa," JIM UPB (Jurnal Ilmiah Manajemen Universitas Putera Batam) 7, no. 1 (2019): 57.

8 Ahmad Ulil Albab Al Umar et al., "Peranan Kuliah Kerja Nyata Sebagai Wujud Pengabdian Kepada Masyarakat Di Tengah Pandemi Covid-19 (Studi Kasus Iain Salatiga KKN 2021),” E-Amal1, no. 1 (January 1, 2021$): 40$.
} 
Selain lembaga formal yang harus menghentikan operasionalnya, lembaga bersifat non-formal seperti taman pendidian al-Qur'an (TPQ) maupun madrasah diniyah (MI) juga ikut menghentikan kegiatan akibat pandemi covid-19. Sehingga para peserta didik atau santriwan harus melakukan pembelajaran melalui daring. Seiring berjalannya waktu, justru lembaga non-formal memulai lebih dulu untuk mengadakan pembelajaran secara tatap muka atau langsung. Selama para pendidik dan peserta didiknya mematuhi protokol kesahatan dan perlu mengevaluasi lebih lanjut mengenai diperbolehkannya beroperasi agar tidak menjadi hal yang tidak diinginkan. ${ }^{9}$

Pendidikan agama adalah salah satu materi yang dapat membantu dalam usaha menumbuhkan perilaku baik untuk peserta $\operatorname{didik}^{10}$. Sifat serta perilaku mereka yang sesuai pedoman agama merupakan cerminan sukses pendidik dalam mengajar serta merupakan bentuk manusia yang baik dan sebuah keberhasilan dalam edukasi. ${ }^{11}$ Salah satu materi pelajaran yang harus dan wajib didapatkan siswa dari pendidikan agama Islam adalah Fikih. Yaitu materi yang berisi tuntunan atau tata cara manusia dalam beribadah kepada Allah Swt. tanpa Fikih manusia akan melakukan ibadah atau perilaku cara yang kurang benar, bahkan dikatakan salah. Maka dari itu, peserta didik harus memahami betul tentang fikih, agar penerapan serta penghayatan dalam aplikasi dikehidupannya dapat diterapkan dengan baik. Dalam rangka mewujudkan hal tersebut, maka harus diimbangi dengan proses pengajaran di kelas yang efektif dan diharapkan bisa memudahkan peserta didik dalam memahami materi Fikih agar materi yang didapatkan bisa benar-benar tertanam dalam diri peserta didik. $^{12}$

Salah satu cabang dari ilmu keIslaman adalah Fikih, berkaitan dengan masalah hukum syariat yang mana berisi tentang hubungan makhluk-Nya dengan Allah (bablum minallab) dan relasi antar manusia satu dengan manusia lainnya. Definisi Fikih secara etimologi, berarti paham/mengerti. Hal yang melatarbelakangi Fikih medapatkan pengertian yang universal adalah pemahaman filosofis bahwa Islam dinilai secara kaffah. Penjelasan ini tentu punya sandaran pada aspek sejarahnya pada saat para sahabat dan para tabi'in hidup. Kemudian berlanjut ke masa Muta'akbirin yaitu sekitar abad IV-XII H, makna Fikih berubah menjadi sebuah pengetahuan hukum syara' yang bersifat berdasar dari dalil-dalil yang spesifik". ${ }^{13}$

\footnotetext{
9 Waslah et al., "Pelatihan Pembelajaran Tajwid Di TPQ Al Hidayah Desa Brodot Jombang," JUMAT 1, no. 1 (December 2020): 22.

${ }^{10}$ Agus Miftakus Surur, "Peningkatan Kemampuan Khatabah (Public Speaking Skill) Santri Ma’had Darul Hikmah IAIN Kediri,” Ijaz Arabi Journal of Arabic Learning 1, no. 2 (2018).

11 Atika Fitriani and Eka Yanuarti, "Upaya Guru Pendidikan Agama Islam Dalam Menumbuhkan Kecerdasan Spiritual Siswa,” Belajea 3, no. 2 (2018): 177.

12 Raden Rizky Amaliah, Abdul Fadhil, and Sari Narulita, "Penerapan Metode Ceramah Dan Diskusi Dalam Meningkatkan Hasil Belajar PAI Di SMA Negeri 44 Jakarta,” Jurnal Studi Al-Qur’an, 10, no. 2 (2014): 121.

13 Wahbah Zuhaili, Fiqih Imam Syafii (Jakarta: Almahira, 2010), 7.
} 
Karakteristik Mata pelajaran Fikih pada jenjang dasar berisi tentang orientasi dan pemahaman terkait penerapan rukun Islam dalam aspek kehidupan keseharian peserta didik. Sehingga disebut dengan Fikih ibadah, sedangkan Fikih muamalah berkaitan dengan orientasi sederhana dalam pemahamannya. ${ }^{14}$ Ruang lingkupnya sendiri yaitu: Fikih ibadah meliputi: orientasi dan pemahaman terkait penerapan rukun Islam dalam aspek kehidupan keseharian peserta didik, seperti: bersuci, sholat, puasa, zakat, serta berhaji. Sedangkan Fikih muamalah meliputi: orientasi dan pemhaman tentang ketentuan makanan dan minuman halal maupun haram, bersunat (khitan), berkurban, mengetahui tata cara jual beli serta pinjam-meminjam. ${ }^{15}$

Pemahaman adalah sebuah potensi yang membuat peserta didik dalam memahami dan mengerti dalam hal bahan yang tersampaikan kepada peserta didik dan mampu memakainya tanpa harus mengkorelasikan dengan hal-hal lainnya. Kemampuan pemahaman sendiri dijelaskan secara rinci dalam tiga bentuk, yaitu menterjemahkan, mentafsirkan dan mengekstrapolasikan. ${ }^{16}$ Dalam artian secara luas, pemahaman adalah mampu mendapatkan intelektual yang sudah pernah diajari. mencakup bagaimana cara menulis atau menyampaikan kembali hasil dari apa yang didengarrnya. Pemahaman adalah suatu kelebihan dalam menguasai inti dari sebuah materi atau hal apa dan sedang dipahami. Sedangkan dalam belajar, merupakan proses kegiatan dalam rangka merubah perilaku peserta didik secara kontruktif dan berkelanjutan. ${ }^{17}$

Tempat pengabdian ini berada di lembaga TPQ al-Hikmah kelurahan Ngronggo kota Kediri yaitu sebelah barat kantor kelurahan Ngronggo atau lebih tepatnya di area sekitar masjid alHikmah. Bagian wilayah kota Kediri bagian tengah menjadikan tidak terlalu padat penduduk dan masih termasuk pinggiran kota. Termasuk wilayah strategis dan Sebagian besar anak yang tumbuh dan berkembang di kelurahan Ngronggo memiliki tingkat pendidikan yang baik. Para orang tua juga mendukung penuh setiap jenjang pendidikan yang ditempuh oleh anaknya. Salah satunya memasukkan mereka ke lembaga taman pendidian al-Qur'an (TPQ) untuk memperdalam ilmu agama. Berdiri sejak 15 tahun yang lalu membuat orang-orang khususnya wilayah sekitar tidak asing lagi pada lembaga pendidikan al-Qur'an tersebut. bahkan sampai saat ini pun masih dipercaya para warga untuk menitipkan anak-anaknya agar belajar membaca al-Qur'an dan ibadah lainnya.

Apalagi kondisi pandemi Covid-19 yang melanda Indonesia, membuat menghentikan sementara kegiatan pendidikan yang bersifat perkumpulan. Namun melihat perkembangannya lembaga seperti TPQ al-Hikmah dimasukkan kembali selama mematuhi protokol kesehatan. Sehingga guna memenuhi tugas pengabdian, maka ikut urtuk membantu sekaligus belajar agar mendapatkan

\footnotetext{
14 Markaban and Mahbib Khairan, Buku Siswa Fikih Kelas V (Jakarta: Kemenag RI, 2020), 3.

15 Sapiudin Shidiq, Fikih Kontemporer (Jakarta: Kencana, 2017), 7.

16 Zainal Arifin, Evaluasi Pembelajaran: Prinsip Teknik Prosedur (Bandung: Remaja Rosdakarya, 2012), 21.

${ }^{17}$ Nanang Hanafiah and Cucu Suhana, Konsep Strategi Pembelajaran (Bandung: Refika Aditama, 2010), $20-21$.
} 
pengalaman secara di lapangan. Dalam masa pandemi muncul berbagai permasalahan pendidikan, salah satunya adalah kesulitan belajar daring, kesulitan memahami materi pembelajaran, fasilitas dirumah kurang memadai, rumitnya tugas yang diberikan sekolah, dan pengalaman orang tua yang minim dalam mendampingi anak belajar dirumah. Salah satunya mengajarkan pelajaran Fikih kepada anak. Tentu hal itu menjadi hambatan jikalau anak tersebut ingin beridabah tetapi tidak tahu ilmunya maka akan menimbulkan ketidaktahuan.

Dengan adanya program Kuliah Kerja Nyata IAIN Kediri, pengabdian ini bertujuan untuk mengembangkan pembelajaran Fikih menggunakan metode demonstrasi sebagai salah satu alternatif pengajaran Fikih selama masa pandemi yang dilakukan di kelurahan Ngronggo kota Kediri. Diharapakan dengan adanya program KKN-DR ini juga dapat membantu masyarakat dalam mengatasi kesulitan pembelajaran Fikih selama masa pandemi. Tujuan lain dari penelitian ini adalah memberikan gambaran tentang pembelajaran Fikih sebagai upaya untuk membangun pemahaman peserta didik demi pendidikan Indonesia yang lebih baik.

\section{METODE}

Metode yang digunakan dalam kegiatan pengabdian ini adalah Participatory Action Research (PAR), metode ceramah dan demonstrasi. Participatory Action Research (PAR) adalah metode riset yang dilaksanakan secara partisipatif di antara warga masyarakat dalam suatu komunitas aras bawah yang semangatnya untuk mendorong terjadinya aksi-aksi transformatif melakukan pembebasan masyarakat dari belenggu ideologi dan relasi kekuasan (perubahan kondisi hidup yang lebih baik). Dilaksanakan dengan mengacu metodologi riset tertentu, harus bertujuan untuk mendorong aksi transformatif, dan harus melibatkan sebanyak mungkin masyarakat warga atau anggota komunitas sebagai pelaksana PAR-nya sendiri. PAR merupakan kegiatan riset yang berbeda dengan metode penelitian ilmiah lainnya yang biasa dilakukan oleh para akademisi, lembaga survey, dll. Di dalam metode penelitian ilmiah pada umumnya seorang pengabdi menjadikan suatu kelompok masyarakat hanya sebagai objek yang diteliti untuk mendapatkan suatu inti permasalahan tanpa memberikan perubahan (transformasi) nilai di dalam suatu masyarakat tersebut. ${ }^{18}$

Menurut Syaiful Sagala, metode ceramah yaitu bentuk interaksi malalui menerangkan dalam bentuk lisan dari pendidik ditujukan untuk peserta didik. Pelaksanaannya sendiri bisa memakai unsur pendukung seperti visualisasi maupun audio-visual guna membantu dalam menjelaskan materi. ${ }^{19}$ Sedangkan Syaiful Basri Djamaran dan Aswan Zain mendefinisikan sebagai alat komunikatif

\footnotetext{
18 Buku Panduan: Kuliah Kerja Nyata Dari Rumah (KKN-DR) LAIN Kediri 2021 (Kediri: Lembaga Penelitian dan Pengembangan Masyarakat (LP2M) IAIN KEDIRI, 2021), 79.

19 Syaiful Sagala, Konsep Dan Makna Pembelajaran Untuk Memecabkan Problematika Belajar Dan Mengajar (Bandung: Alfabeta, 2009), 201.
} 
lisan antar pendidik dengan peserta didiknya dalam kegiatan pembelajaran. ${ }^{20}$ Pendapat lainnya yaitu Wina Sanjaya mengatakan kalau metode ceramah diartikan sebagai cara menyajikan pelajaran melalui penjelasan secara lisan atau berkomunikasi langsung dengan semua peserta didik di kelas. ${ }^{21}$ berdasarkan pandangan ahli terkait pengertian metode ceramah dapat ditarik sebuah benang merah yaitu sebuah interaksi antara pendidik dan peserta didik melalui media komunikasi lisan atau secara langsung.

Metode demonstrasi ialah sebuah merode dimana cara mengajar menggunakan peraga untuk memperjelas suatu konsep atau untuk menampilkan bagaiman suatu proses bentuk tertentu kepada peserta didik. Sedangkan peraganya sendiri adalah pendidik sendiri atau anak didik itu sendiri. ${ }^{22}$ kelebihan dari metode ini yaitu Perhatian anak didik bisa terpusatkan dari apa yang telah didemonstrasikan sehingga lebih mempunyai arah dan memberikan kefokusan dalam hal yang dipelajari, mampu menstimulasikan peserta didik agar leih aktif dalam kegiatan pembelajaran, memberikan pengalaman kepada peserta didik, membantu peserta didik mengingat melalui gerakan atau peragaan, serta memperjelas suatu materi pelajaran dan menjawab semua masalah yang dipikirkan oleh manusia. ${ }^{23}$

\section{PEMBAHASAN}

Pada program pengabdian KKN IAIN Kediri, dikenalkan bagaimana cara memahami materi Fikih menggunakan metode demonstrasi. Metode digunakan adalah Participatory Action Research (PAR) yang mana peserta KKN-DR mengikuti sebagai partisipan dari kegiatan yang telah ada sehingga merasakan langsung bekerja di lapangan. Program ini dilaksanakan dalam pertemuan selama tiga kali dalam satu seminggu. Bersama anak-anak TPQ al-Hikmah yang menjadi subyek berjumlah 12 orang dari berbagai umur dan jenjang sekolah. Dibantu oleh para guru TPQ al-Hikmah untuk mengkoordinasi serta membantu jalannya proses kegiatan mengajar. Dengan menyiapkan desain rancangan hipotesis rancangan belajar yaitu:

Tabel 1. Kurikulum materi Taharah

\begin{tabular}{|l|l|}
\hline Kompetensi & - Mengidentifikasi pengertian thaharah dan pembagian air serta macam-macamnya \\
Dasar & - Menjelaskan dan mempraktekkan tata cara thaharah dengan baik dan benar \\
& $\begin{array}{l}\text { - Menjelaskan tentang pengertian, keistimewaan, rukun, sunnah dan yang } \\
\text { membatalkan wudhu }\end{array}$ \\
\hline
\end{tabular}

20 Syaiful Bahri Djamarah and Aswan Zain, Strategi Belajar Mengajar (Jakarta: Rineka Cipta, 2006 ), 97.

21 Sanjaya Wina, Strategi Pembelajaran Berorientasi Standar Proses Pendidikan (Jakarta: Media Group, 2010), 147.

22 Fince, Achmad Ramadhan, and Yusdin Gagaramusu, "Penerapan Metode Demonstrasi Untuk Meningkatkan Hasil Belajar Siswa Pada Materi Penyebab Benda Bergerak Di Kelas 1 SDN Dampala Kec. Bahodopi Kab. Morowali," Jurnal Kreatif Tadulako Online 3, no. 1 (2015): 220.

${ }^{23}$ Fathurrahman, Metode-Metode Pembelajaran (Jakarta: Universitas Terbuka, 2008), 54. 


\begin{tabular}{|c|c|}
\hline & - mempraktekkan tata cara wudhu dengan baik dan benar \\
\hline Materi & $\begin{array}{l}\text { a. Pengertian Thaharah } \\
\text { b. Macam-macam air } \\
\text { c. Pembagian air } \\
\text { d. Pengertian Wudhu } \\
\text { e. Keistimewaan Wudhu } \\
\text { f. Syarat-syarat Wudhu } \\
\text { g. Rukun Wudhu } \\
\text { h. Sunnah Wudhu } \\
\text { i. Yang membatalkan Wudhu }\end{array}$ \\
\hline $\begin{array}{l}\text { Tujuan } \\
\text { Pembelajaran }\end{array}$ & $\begin{array}{l}\text { - Mampu mengetahui tentang thaharah dan pembagian air serta macam-macamnya } \\
\text { - Mampu menjelaskan dan mempraktekkan bagaimana tata cara thaharah } \\
\text { - Mampu menjelaskan tentang pengertian, keistimewaan, rukun, sunnah dan yang } \\
\text { membatalkan wudhu } \\
\text { - mampu mempraktekkan tata cara wudhu dengan baik dan benar }\end{array}$ \\
\hline
\end{tabular}

Setelah menyusun rancangan belajar kemudian melaksanakan rangkaian aktivitas perencanaan yang berisi tiga kegiatan yaitu

a. Kegiatan pertama dilaksanakan pada tanggal 15 Juli 2021 Menyiapkan anak-anak untuk siap dalam menerima pelajaran secara keseluruhan serta materi yang sudah disediakan yaitu tentang thaharah. Merancang perencanaan dengan membuat rencana pelaksanaan pembelajaran (RPP). Isinya tentang tempat, jadwal serta waktu pembelajaran sesuai dengan materi yang akan diajarkan. Tidak lupa untuk mengecek kembali apa yang masih kurang agar persiapan awal lebih matang.

Kegiatan pendahuluan diisi dengan awalan dari pendidik dengan mengucapkan salam terlebih dahulu kepada peserta didiknya, lalu menjawab salam dari pendidik. Kemudian pendidik meminta untuk membaca kebiasaan sebelum masuk ke pembelajaran. anak-anak biasanya membaca surah al-Fatihah bersama dilanjutkan dengan membaca doa sebelum belajar. Selepas itu, pendidik mulai memeriksa kehadiran dari peserta didik dengan menggunakan jurnal absensi siswa dan melihat siapa yang tidak hadir pada pertemuan itu. Pendidik mulai menjelaskan kepada anak-anak tentang pentingnya thaharah kemudian masuk ke pengertian thaharah dengan jelas agar semuanya mendengar dan sembari menunjuk beberapa anak untuk mengulang kembali tentang apa yan telah dijelaskan. 
Kegiatan penutup digunakan untuk menguraikan kembali materi yang sudah disampaikan dan mengajak anak-anak untuk menyimpulkan pemahamannya tentang materi hari ini. Kemudian kelas pun berakhir dengan membaca surat al-Ashr sebagai penutup pertemuan kali ini dan mengucapkan salam kepada pendidik. Lalu bersiap untuk sholat isya' berjamaah. Pengamatan dilakukan secara langsung dalam hal mengamati semua aktivitas anak-anak dalam kegiatan proses pembelajaran menggunakan metode ceramah. Melihat secara langsung ada beberapa anak belum sepenuhnya paham tetapi dengan beberapa kali ulangan isa menjadi solusi untuk masalah itu. Dalam kegiatan pertama, bisa dikatakan berhasil dari awal sampai akhir kegiatan. Namun karena kurangnya waktu dalam pembelajaran, tidak bisa menadi maksimal. Apalagi para anak-anak yang sering kehilangan fokus dalam pembelajaran membuat kehilangan banyak waktu untuk mengondisikan. Tetapi dengan begini bisa menjadi bahan evaluasi untuk mengefektifkan kegiatan pembelajaran selanjutnya.

b. Kegiatan kedua dilaksanakan pada tanggal 22 Juli 2021 dengan mempersiapkan anak-anak untuk siap dalam menerima pelajaran secara keseluruhan serta materi yang sudah disediakan yaitu tentang wudhu. Setelah kemarin membahas tentang bersuci, kemudian pendidik mencoba melanjutkan ke materi selanjutnya yaitu wudhu. Sehingga kali ini berfokus pada pemberian materi kepada anak-anak sebelum praktek atau mendemonstrasikannya.

Kegiatan pendahuluan diisi dengan awalan dari pendidik dengan mengucapkan salam terlebih dahulu kepada peserta didiknya, lalu menjawab salam dari pendidik. Kemudian pendidik meminta untuk membaca kebiasaan sebelum masuk ke pembelajaran. anak-anak biasanya membaca surah al-Fatihah bersama dilanjutkan dengan membaca doa sebelum belajar. Selepas itu, pendidik mulai memeriksa kehadiran dari peserta didik dengan menggunakan jurnal absensi siswa dan melihat siapa yang tidak hadir pada pertemuan itu. Kemudian pendidik menyapa dengan bertanya tentang kabar peserta didik diiringi beberapa canda tawa agar awalan tidak merasa kaku. Pendidik mulai mengulang sedikit pembahasan materi sebelumnya lalu melakukan apersepsi dengan materi wudhu. Pendidik mulai menjelaskan kepada anak-anak tentang pentingnya wudhu kemudian masuk ke pengertian wudhu dengan jelas agar semuanya mendengar serta menjelaskan apa saja rukun dan sunnah wudhu. Tak terkecuali yaitu hal-hal yang membatalkan wudhu dengan mengingat kembali kebiasaan anak-anak setiap akan berwudhu.

Kegiatan penutup digunakan untuk menguraikan kembali materi yang sudah disampaikan dan mengajak anak-anak untuk menyimpulkan pemahamannya tentang materi hari ini. Kemudian kelas pun berakhir dengan membaca surat al-Ashr sebagai penutup pertemuan kali 
ini dan mengucapkan salam kepada pendidik. Lalu bersiap untuk sholat isya' berjamaah. Pengamatan dilakukan secara langsung dalam hal mengamati semua aktivitas anak-anak dalam kegiatan proses pembelajaran menggunakan metode ceramah. Melihat secara langsung ada beberapa anak belum sepenuhnya paham tetapi dengan beberapa kali ulangan bisa menjadi solusi untuk masalah itu. Dalam kegiatan kedua, pendidik melanjutkan ntuk mengganti materi yang diajarkan sebagai jenjang selanjutnya. Dapat dikatakan berhasil dari awal sampai akhir kegiatan kedua ini. Namun kali ini berbekal evaluasi dari kegiatan sebelumnya, dalam hal keefektikan waktu menjadi salah satu yang dipikirkan agar menjadi efisien. Sehingga anak-anak bisa langsung masuk ke tahap selanjutnya yaitu mendemonstrasikan materi wudhu ke kegiatan selanjutnya.

c. Kegiatan ketiga dilaksanakan pada tanggal 15 Agustus 2021 dengan mempersiapkan anakanak untuk siap dalam mempraktekkan hasil materi wudhu yang telah dijelaskan kegiatan sebelumnya. Kegiatan pendahuluan diisi dengan awalan dari pendidik dengan mengucapkan salam terlebih dahulu kepada peserta didiknya, lalu menjawab salam dari pendidik. Kemudian pendidik meminta untuk membaca kebiasaan sebelum masuk ke pembelajaran. anak-anak biasanya membaca surah al-Fatihah bersama dilanjutkan dengan membaca doa sebelum belajar. Selepas itu, pendidik mulai memeriksa kehadiran dari peserta didik dengan menggunakan jurnal absensi siswa dan melihat siapa yang tidak hadir pada pertemuan itu.

Pendidik memulai dengan menyampaikan kepada siswa bahwa hari ini akan mempraktikan wudhu, apa tujuan yang harus dicapai oleh siswa serta menghubungkan pelajaran yang lalu (sebelum tindakan) dengan pelajaran yang telah dipelajari. Setelah selesai pendidik memanggil anak-anak maju ke depan sesuai dengan nama yang terpanggil. Dalam melalukan praktik ini, untuk menghemat waktu pendidik memanggil lima anak sekaligus untuk melakukan praktik wudhu secara bersamaan dan pendidik bertindak sebagai pembimbing terhadap anakanak. Selama praktik dilakukan, selalu peneliti sebagai pendidik juga sebagai observer. Tugas dari observer ini adalah mengobservasi atau menilai kegiatan guru dan kegiatan siswa sesuai format yang telah dibuat selama pembelajaran. Ketika siswa melakukan praktik wudhu, guru langsung memberikan penilaian kepada siswa terhadap praktik yang dilakukannya. Penilaian yang diberikan kepada siswa adalah sesuai dengan indikator keberhasilan siswa dalam belajar. Indikator tersebut terdiri dari sembilan yang akan dinilai, yaitu mulai dari membaca bismillah sampai kepada membaca do'a selesai berwudhu. Adapun hasil observasi kegiatan siswa dapat dilihat pada Indikator yang telah diajarkan yaitu:

1) Membasuh telapak tangan sambil mengucapkan Bismillahir Rahmanir Rahim

2) Berkumur-kumur $3 x$ 
3) Membersihkan lubang hidung

4) Membasuh muka sebanyak $3 x$ mulai dari tumbuhnya rambut kepala sampai ke dagu sambil membaca niat wudhu Nawaitul wudhun'a li raf'il hadatsil ashghari fardhal lillabi ta'ala

5) Membasuh tangan sampai siku

6) Membasuh sebagian kepala dan telinga

7) Membasuh kaki sampai dengan mata kaki

8) Membaca doa setelah wudhu

9) Tertib.

Setelah diamati bahwa anak-anak sudah melaksanakan kegiatan demonstrasi dengan baik, walaupun ada beberapa anak yang belum atau lupa urutan wudhu serta doa setelah wudhu karena terlalu panjang dan tidak terbiasa maka ada yang sudah hafal atau masih setengah hafal. Dalam kegiatan ketiga, setelah memperhatikan beberapa hal di kegiatan selanjutnya. Maka memulai kegiatan mendemonstrasikan wudhu secara langsung. Walapun tidak sepenuhnya semua berhasil. Tetapi anak-anak sudah dikatakan mampu mendemonstrasikan dan merealisasikan materi wudhu yang telah diajarkan dalam kegiatan sebelumnya. Sehingga kegiatan sudah selesai di siklus ketiga ini. Untuk kedepannya juga telah mendiskusikan dengan pendidik asli untuk memberitahu kendala maupun pencapaian anak-anak dalam kegiatan pengabdian berupa pengajaran kali ini.

Kegiatan pengabdian KKN-DR IAIN Kediri yang dilaksanakan di kelurahan Ngronggo tepatnya di TPQ al-Hikmah berjalan dengan baik. Dengan tujuan menerapkan salah satu tri dharma mahasiswa, mahasiswa berperan mengikuti program atau kegiatan yang sekiranya berada dalam lingkup masyarakat. Pembahasan tentang hasil kegiatan pembelajaran dalam mengajarkan materi Fikih menggunakan metode demonstrasi yang dilakukan selama tiga siklus atau tiga kegiatan. Dimana kegiatan petama diisi dengan memberikan materi awal dari bahasan Fikih yaitu thaharah. Kemudian sekiranya cukup dengan materi sebelumnya maka dilanjutkan materi selanjutnya yaitu wudhu dan terakhir kegiatan ketiga diisi dengan praktek wudhu sebagai hasil akhir.

Kegiatan pertama menunjukkan bahwa anak-anak sudah mengerti bagian pengertian thaharah dan macam-macam air serta pembagiannya. Walapun saat diminta menjelaskan kembali tidak sama seperti yang telah diajarkan, namun mereka memakai kata-kata sendiri agar sesuai dengan pemahamannya. Tidak juga terlalu berbeda namun makna dari jawaban anak-anak sudah sama. Namanya kegiatan awal pasti ada kendala seperti kurangnya waktu dalam pembelajaran, tidak bisa menadi maksimal. Apalagi para anak-anak yang sering kehilangan fokus dalam pembelajaran membuat kehilangan banyak waktu untuk mengondisikan. Tetapi dengan begini bisa menjadi bahan 
evaluasi untuk mengefektifkan kegiatan pembelajaran selanjutnya. Atas evalasi tersebut dijadikan penentu untuk melanjutkan materi selanjutnya yaitu pembahasan wudhu.

Kegiatan pertama menunjukkan adanya keberhasilan, sehingga dalam kegiatan pembelajaran kedua memutuskan mengganti materi dengan wudhu. Dalam hal ini kegiatan masih bersifat sama dengan sebelumnya. Memberikan materi wudhu pada awal sampai akhir sebelum pendidik mencontohkan di depan anak-anak. mengamati semua aktivitas anak-anak dalam kegiatan proses pembelajaran menggunakan metode ceramah. Melihat secara langsung ada beberapa anak belum sepenuhnya paham tetapi dengan beberapa kali ulangan bisa menjadi solusi untuk masalah itu. Tetapi kali ini berbekal evaluasi dari kegiatan sebelumnya, dalam hal keefektikan waktu menjadi salah satu yang dipikirkan agar menjadi efisien. Sehingga anak-anak bisa langsung masuk ke tahap selanjutnya yaitu mendemonstrasikan materi wudhu ke kegiatan selanjutnya.

Pada kegiatan ketiga anak-anak mulai mendemonstrasikan wudhu secara langsung. Walapun tidak sepenuhnya semua berhasil. Tetapi anak-anak sudah dikatakan mampu mendemonstrasikan dan merealisasikan materi wudhu yang telah diajarkan dalam kegiatan sebelumnya. Sehingga kegiatan sudah selesai di siklus ketiga ini. Untuk kedepannya juga telah mendiskusikan dengan pendidik asli untuk memberitahu kendala maupun pencapaian anak-anak dalam kegiatan pengabdian berupa pengajaran kali ini. Dengan memenuhi kriteria indikator 1) Membasuh telapak tangan sambil mengucapkan Bismillahir Rahmanir Rahim; 2) Berkumur-kumur 3x; 3) Membersihkan lubang hidung; 4) Membasuh muka sebanyak 3x mulai dari tumbuhnya rambut kepala sampai ke dagu sambil membaca niat wudhu Nawaitul wudhuu'a li rafil hadatsil ashghari fardhal lillahi ta'ala; 5) Membasuh tangan sampai siku; 6) Membasuh sebagian kepala dan telinga; 7) Membasuh kaki sampai dengan mata kaki; 8) Membaca doa setelah wudhu; 9) Tertib.

Dengan adanya penerapan metode yang tepat dalam proses pembelajaran pada peserta didik maka sebaiknya sebagai seorang Guru harus lebih kreatif lagi dalam penggunaan metode agar dalam proses pembelajaran tidak membosankan dan dapat mengembangkan potensi baik dari Guru maupun dari siswa sendiri. ${ }^{24}$ melihat ungkapan tersebut bisa dijadikan acuan bahwa kegiatan pengajaran Fikih menggunakan metode demonstrasi bisa selesai dan terealisasikan serta menjadi acuan dalam menjadi alternatif salah satu cara atau metode untuk mengajarkan pembelajaran sesuai situasi dan kondisi. Sehingga kegiatan pengabdian ini bisa menjadi pengalaman dan pembelajaran untuk bekal akademisi mahasiswa selama KKN-DR IAIN Kediri tahun 2021.

${ }^{24}$ Wina, Strategi Pembelajaran Berorientasi Standar Proses Pendidikan, 34. 


\section{SIMPULAN}

Selama masa pandemi, banyak masalah baru yang muncul sebagai salah satu bentuk adaptasi terhadap keadaaan yang sedang dihadapi. Salah satu permasalahan yang timbul adalah pendidikan di masa pandemi yang menimbulkan berbagai pro dan kontra. Bentuk nyata permalahan di bidang pendidikan adalah peralihan dari ruang kelas offline menjadi virtual, minimnya interaksi antara guru dan murid dalam sistem pembelajaran, kurangnya fasilitas sekolah daring, kesulitan pengerjaan tugas dalam sekolah daring dan yang lainnya. permasalahan ini timbul karena adanya penyesuaian diri terhadap situasi yang dialami, namun juga diperlukan solusi yang tepat untuk mengatasinya. Untuk mengembangkan pembelajaran Fikih menggunakan metode demonstrasi sebagai salah satu alternatif pengajaran Fikih selama masa pandemi yang dilakukan di kelurahan Ngronggo kota Kediri. Diharapakan dengan adanya program KKN-DR ini juga dapat membantu masyarakat dalam mengatasi kesulitan pembelajaran Fikih selama masa pandemi.

Kegiatan pengabdian KKN-DR IAIN Kediri yang dilaksanakan di kelurahan Ngronggo tepatnya di TPQ al-Hikmah berjalan dengan baik. Dengan tujuan menerapkan salah satu tri dharma mahasiswa, mahasiswa berperan mengikuti program atau kegiatan yang sekiranya berada dalam lingkup masyarakat. Pembahasan tentang hasil kegiatan pembelajaran dalam mengajarkan materi Fikih menggunakan metode demonstrasi yang dilakukan selama tiga siklus atau tiga kegiatan. Dimana kegiatan petama diisi dengan memberikan materi awal dari bahasan Fikih yaitu thaharah. Kemudian sekiranya cukup dengan materi sebelumnya maka dilanjutkan materi selanjutnya yaitu wudhu dan terakhir kegiatan ketiga diisi dengan praktek wudhu sebagai hasil akhir.

Walaupun ada kendala terkait efisiensi dan kondusif anak-anak, bisa diperbaiki seiring berjalannya kegiatan pembelajaran secara rutin. Dengan begitu kegiatan pengajaran Fikih menggunakan metode demonstrasi bisa selesai dan terealisasikan serta menjadi acuan dalam menjadi alternatif salah satu cara atau metode untuk mengajarkan pembelajaran sesuai situasi dan kondisi. Tidak lupa untuk mendiskusikan hasil kegiatan bersama pendidik untuk mendapatkan solusi dari berbagai permasalahan.

\section{REKOMENDASI}

Dari hasil pembelajaran di atas dapat diberikan saran untuk beberapa pihak. Pertama untuk masyarakat: Selalu menjaga kesehatan baik jiwa dan raga dengan mematuhi segala protokol kesehatan yang diterapkan oleh Pemerintah, serta menghindari stress yang berlebihan. Selalu mendukung kegiatan pendidikan yang dilakukan oleh anak dimasa pandemi dengan memberikan bantuan moral dan semangat.Menjadi figur masyarakat yang selalu taat aturan dan hukum demi keberlangsungan kegiatan dimasa pandemi 
Kedua yatu untuk para Pendidik, yaitu Selalu menjaga kesehatan baik jiwa dan raga dengan mematuhi segala protokol kesehatan yang diterapkan oleh Pemerintah, serta menghindari stress yang berlebihan. Melakukan inovasi dalam pengajaran selama pandemi sehingga anak akan tertarik selama belajar dirumah. Menggunakan strategi pembelajaran yang tepat agar kegiatan belajar mengajar dirumah semakin menyenangkan Memberikan bantuan moral dan semangat kepada anak agar tetap bahagia menjalani hari dimasa pandemi, serta tidak lupa untuk mengingatkan anak agar selalu menjaga kesehatan

Selanjutnya ketiga, untuk Lembaga pendidikan, yaitu memberikan contoh kepada akademisi maupun masyarakat untuk selalu menjaga kesehatan dan mengikuti protokol kesehatan yang berlaku. Memberikan inovasi terhadap sistem pembelajaran dirumah selama masa pandemi yang tidak memberatkan dan dapat diakomodasi oleh seluruh lapisan masyarakat. Meningkatkan kualitas pendidikan anak selama masa pandemi dengan sistem pembelajaran yang tepat.

\section{DAFTAR PUSTAKA}

Amaliah, Raden Rizky, Abdul Fadhil, and Sari Narulita. "Penerapan Metode Ceramah Dan Diskusi Dalam Meningkatkan Hasil Belajar PAI Di SMA Negeri 44 Jakarta,” Jurnal Studi Al-Qur'an, 10, no. 2 (2014): 119-131.

Arifin, Zainal. Evaluasi Pembelajaran: Prinsip Teknik Prosedur. Bandung: Remaja Rosdakarya, 2012.

Astini, Ni Komang Suni. "Pemanfaatan Teknologi Informasi Dalam Pembelajaran Tingkat Sekolah Dasar Pada Masa Pandemi Covid--19.” LAMPUHYANG 11, no. 2 (July 1, 2020): 13-25.

Buku Panduan: Kuliah Kerja Nyata Dari Rumah (KKN-DR) IAIN Kediri 2021. Kediri: Lembaga Penelitian dan Pengembangan Masyarakat (LP2M) IAIN KEDIRI, 2021.

Djamarah, Syaiful Bahri, and Aswan Zain. Strategi Belajar Mengajar. Jakarta: Rineka Cipta, 2006.

Fathurrahman. Metode-Metode Pembelajaran. Jakarta: Universitas Terbuka, 2008.

Fince, Achmad Ramadhan, and Yusdin Gagaramusu. "Penerapan Metode Demonstrasi Untuk Meningkatkan Hasil Belajar Siswa Pada Materi Penyebab Benda Bergerak Di Kelas 1 SDN Dampala Kec. Bahodopi Kab. Morowali.” Jurnal Kreatif Tadulako Online 3, no. 1 (2015): 218231. 


\section{Yahya Khabibi, Agus Miftakus S, Agus Subandono}

Fitriani, Atika, and Eka Yanuarti. "Upaya Guru Pendidikan Agama Islam Dalam Menumbuhkan Kecerdasan Spiritual Siswa.” Belajea 3, no. 2 (2018): 174-202.

Hakim, Rosyid Ridlo Al. "Pencegahan Penularan Covid-19 Berbasis Aplikasi Android Sebagai Implementasi Kegiatan KKN Tematik Covid-19 Di Sokanegara Purwokerto Banyumas.” Community Engagement and Emergence Journal (CEEJ) 2, no. 1 (2020): 7-13.

Hanafiah, Nanang, and Cucu Suhana. Konsep Strategi Pembelajaran. Bandung: Refika Aditama, 2010. Markaban, and Mahbib Khairan. Buku Siswa Fikih Kelas V. Jakarta: Kemenag RI, 2020.

Pujiasih, Erna. "Membangun Generasi Emas Dengan Variasi Pembelajaran Online Di Masa Pandemi Covid-19.”' Ideguru: Jurnal Karya Ilmiah Guru 5, no. 1 (2020): 42-48.

Pujilestari, Yulita. "Dampak Positif Pembelajaran Online Dalam Sistem Pendidikan Indonesia Pasca Pandemi Covid--19.”' 'ADALAH 4, no. 1 (April 19, 2020): 24-35. https://doi.org/10.15408/adalah.v4i1.15394.

Sagala, Syaiful. Konsep Dan Makna Pembelajaran Untuk Memecahkan Problematika Belajar Dan Mengajar. Bandung: Alfabeta, 2009.

Shidiq, Sapiudin. Fikih Kontemporer. Jakarta: Kencana, 2017.

Surur, Agus Miftakus. "Peningkatan Kemampuan Khatabah (Public Speaking Skill) Santri Ma'had Darul Hikmah IAIN Kediri.” Ijaz Arabi Journal of Arabic Learning 1, no. 2 (2018).

Surur, Agus Miftakus, Pandi Rais, and Habib. "The Application Program of The Preparation of The Syllabus and Learning Implementation Plan (RPP) 2013 Curriculum on Teachers Madrasah Ibtidaiyah.” Proceedings International Conference on Islamic Education (ICIED) 2, no. 1 (2017): 246-53.

Syardiansah. "Peranan Kuliah Kerja Nyata Sebagai Bagian Dari Pengembangan Kompetensi Mahasiswa." JIM UPB (Jurnal Ilmiah Manajemen Universitas Putera Batam) 7, no. 1 (2019): 50-60.

Umar, Ahmad Ulil Albab Al, Anava Salsa Nur Savitri, Yolanda Sryta Pradani, Mutohar, and Nur Khamid. "Peranan Kuliah Kerja Nyata Sebagai Wujud Pengabdian Kepada Masyarakat Di 
Tengah Pandemi Covid-19 (Studi Kasus Iain Salatiga KKN 2021).” E-Amal 1, no. 1 (January 1, 2021): 39-44.

Waslah, Chusnul Chotimah, Faridatul Hasanah, and M. Abdul Munir Abidin. "Pelatihan Pembelajaran Tajwid Di TPQ Al Hidayah Desa Brodot Jombang." JUMAT 1, no. 1 (December 2020): 21-24.

Wina, Sanjaya. Strategi Pembelajaran Berorientasi Standar Proses Pendidikan. Jakarta: Media Group, 2010.

Zuhaili, Wahbah. Fiqib Imam Syafii. Jakarta: Almahira, 2010. 